\title{
DIGNIDADE HUMANA ATRAVÉS DO ESPELHO: O NOVO TOTEM CONTEMPORÂNEO
}

\section{HUMAN DIGNITY THROUGH THE LOOKING GLASS: THE NEW CONTEMPORARY TOTEM}

${ }^{1}$ Ana Paula Lemes de Souza

\section{RESUMO}

No Brasil, a dignidade humana é erigida como um super princípio. Sob o privilégio de figurar no texto constitucional como um dos fundamentos do Estado Democrático de Direito, é o único direito irrenunciável de todo o ordenamento jurídico. Pode-se renunciar ao direito à vida, mas a dignidade é irrenunciável. Os direitos fundamentais, nesse modelo estatal, formam uma espécie de instituto sistêmico e uniformizante, sendo o princípio máximo a dignidade humana. Os tribunais, sob o pretexto de uma eficácia irradiante, utilizam-na para suplementar as decisões mais diversas. Como princípio norteador do ordenamento jurídico, com base primeira nas religiões, influi decisivamente em todos os demais princípios e, por isso, tornou-se uma espécie de totem contemporâneo. Mas afinal, o que vê a dignidade humana quando confrontada em frente ao espelho? Responder a esta pergunta impõe repensar não só o Estado Democrático de Direito, mas a própria construção aristotélica de um metaprincípio. Objetivase desconstruí-la, tomando como paradigma as obras literárias "As Aventuras de Alice no País das Maravilhas" e "Através do Espelho e o que Alice encontrou por lá", ambas de Lewis Carroll. Igualmente, objetiva-se revelá-la como um suplemento jurídico, identificar a origem terminológica e analisar o seu efeito de pêndulo invertido. Ultima-se a concluir que a dignidade humana nada mais é do que um suplemento jurídico contemporâneo, um estilo de argumentação que justamente por ser impreciso se torna forte, de modo dúplice: bom para o governante e ruim para o governado. Este artigo se utilizará dos aportes teóricos do desconstrutivismo de Jacques Derrida.

Palavras-chave: Desconstrutivismo, Aporias, Suplementos jurídicos, Dignidade humana, Metaprincípio, Direito e literatura

\footnotetext{
${ }^{1}$ Mestranda em Direito pela Faculdade de Direito do Sul de Minas - FDSM, Minas Gerais (Brasil). Estagiário Docente pela Faculdade de Direito do Sul de Minas - FDSM, Minas Gerais (Brasil). E-mail: annapaullals@ymail.com
} 


\begin{abstract}
In Brazil, the human dignity is built like a super principle. Under the privilege to figure in the Constitution as one of the foundations of the Democratic State of Law, it's the only inalienable right of the entire legal system. It's possible to waive the right of life, but dignity is inalienable. Fundamental rights, in this state model, form a kind of systemic and standardizing institute, being the maximum principle the human dignity. The courts, under the guise of a radiant efficiency, use it to supplement various decisions. As a guiding principle of the legal system, with bases first in religions, has a decisive influence in all the other principles and, therefore, became a kind of contemporary totem. But after all, what see the human dignity when confronted in the mirror? Answering this question requires rethinking not only the Democratic State of Law, but the Aristotelian construction of a meta- principle. The objective is to deconstruct it, taking as paradigm the literary works "Alice's Adventures in Wonderland" and "Through the Looking Glass and what Alice found there", both written by Lewis Carroll. Also, the objective is to reveal it as a legal supplement, identify the terminological origin and analyze its inverted pendulum effect. Last to conclude that human dignity is nothing more than a contemporary legal supplement, a style of argumentation that precisely because it is inaccurate, becomes strong, in dual mode: good for the government and bad for the governed. This article will use the theoretical contributions of Jacques Derridas deconstruction.
\end{abstract}

Keywords: Deconstructionism, Aporias, Legal supplements, Human dignity, Metaprinciple, Laws and literature 


\section{INTRODUÇÃO}

Totens são símbolos sagrados indígenas, talhados na madeira originalmente no século XIX, embora se especule que o totemismo esteja presente na humanidade desde a préhistória. A origem da palavra vem de uma tribo da América do Norte, chamada Ojibew, deriva de odoodem e significa "marca de família". São verdadeiros talismãs indígenas, uma espécie de brasão familiar entalhado na forma de uma escultura, que trazem figuras representativas importantes no seio da sociedade primitiva, bem como seus anseios e características. Enquanto símbolo mágico, visa registrar a identidade tribal e é considerado não apenas em sua dimensão sacra, mas uma verdadeira entidade protetora daquela comunidade, com poderes sobrenaturais.

A dignidade da pessoa humana se tornou, no ordenamento jurídico brasileiro, uma espécie de totem, um símbolo sagrado e indefinível, que circula duplamente entre as dimensões mágicas e práticas. Com seu poder simbólico, passou a figurar em demandas das mais diversas, trazendo sentidos cada vez mais distintos e inimagináveis para sua mensagem. Nos tribunais, esse metaprincípio passou a ser uma espécie de mestre ou xamã na grande manta principiológica ordenamentária, e tem se disseminado como uma palavra-chave, ou mantra sagrada, invocada como uma entidade jurídico-protetora dos oprimidos (ou, a depender, também dos poderosos).

Mas afinal, o que é a dignidade humana, e no que esta se digna ao confrontar-se no espelho? O significado da dignidade afronta os maiores potenciais criativos do magistrado: cada cabeça, uma sentença e, em cada sentença, ficções manifestadas como em construções romanescas. Tal significante pode encampar significados sublimes ou mesquinhos, revolucionários ou conservadores, a depender da ótica adotada.

Dignidade é fundamento da República Federativa brasileira, embora tenha carga ideológica, ou principiológica. Não obstante esteja inscrita em um diploma jurídico, a Carta Constituinte, este princípio não opera de forma jurídica, e pode ser invocado na condição de palavra mágica que autoriza o intérprete a sustentar diversas decisões. Dignidade é um sistema, mistura-se com um sistema, pode ser tudo, mas também pode ser nada. Ao materializar algo abstrato, o conceito de dignidade é esvaziado, banalizado, pois se trata de um valor metajurídico, indefinível, sem conceituações claras. Se os limites conceituais são grandes, o Estado ganha, como um pêndulo invertido, e, se os limites são pequenos, o cidadão é quem ganha, pois conhece as regras do jogo. A colocação de algo tão abstrato na 
Constituição é um erro: se ele é retirado do texto legal, parece que deixou de existir, quando, na verdade, sua presença é notória, em que pese dispensar menções.

Falar em dignidade humana, em uma primeira análise, é algo belíssimo, quase um poema perfumando a Carta Constitucional. Sob sua beleza e grandeza, em um passe de mágica, todo o sistema valorativo ganharia um maior brilho, como um sol em um sistema solar, que alimenta a vida de diversos outros planetas, que apenas se banham de resquícios de luz. Como um perfume, ou uma radiante estrela, fulguraria por onde passasse, deixando pequenos pedaços de beleza ou levíssimas nuances olfativas.

Contudo, esse primeiro diagnóstico não parece ser o mais apropriado. Enquanto conceito hiante, corre sério risco de hipertrofia. Ao não dizer nada, também pode dizer tudo. Disso vem seu paradoxo, criando-se, obviamente, um problema de decisionismo.

Há um silêncio ensurdecedor da dignidade. Esta se representa como uma sombra: consegue-se ver, mas não tocar, nem sentir. Embora não haja dúvidas quanto a possuir uma sombra, essa posse em nada acrescenta em termos pragmáticos. Como sombra que é, projetase em decorrência de uma luz (o pensamento humano), uma mera fábula inventada e delineada, decorrente de uma única materialidade, o corpo. Pretende-se, neste artigo, desconstruir esse metaprincípio, de forma a revelá-lo como uma espécie de totem jurídico, o que pode ser deveras perigoso para o direito. O corpo nada mais representa que a própria materialidade das leis, e sua projeção se dá não porque a dignidade humana existe de fato, mas por conta da herança ocidental de origem grega, que remonta à construção de argumentações para lidar com inevitáveis paradoxos. Igualmente, objetiva-se revelar a dignidade humana como um suplemento jurídico, discutir sua terminologia e analisar o seu efeito de pêndulo invertido. Os aportes teóricos escolhidos se darão pelos elementos da crítica desconstrutivista de Jacques Derrida, com técnica de pesquisa bibliográfica.

\section{A DIGNIDADE HUMANA NO PAÍS DAS MARAVILHAS: Um suplemento autorizador do Estado Democrático de Direito}

“mas, além disso, para que Latitude ou Longitude será que estou indo? (Alice não tinha a menor ideia do que fosse Latitude, nem do que fosse Longitude, mas lhe pareciam palavras imponentes para se dizer)." (CARROLL, 2009, p. 15)

Desconstruir é uma técnica do pensador contemporâneo Jacques Derrida, que compõe, 
juntamente com Luhmann (2006) e a teoria dos sistemas, um dos principais expoentes de uma visão pós-ontológica do direito. Desconstruir não é destruir, mas sim buscar a revelação de um mito fundacional. Dissecar as superestruturas para revelar as minimalidades, ou refazer um caminho para encontrar o ponto de partida, refazendo os próprios preceitos ao se refletir por onde andou.

O direito é facilmente desconstruível, já que, muito mais que em outras disciplinas, a ciência jurídica secularmente se sustentou em verdadeiros mitos. Tais criações vão desde formatações de estados até a própria configuração das leis. As verdades cristalizadas do direito são fundadas em discursos retóricos, que, sem fundamentos, apenas recorrem a si mesmos para se sustentarem. O positivismo, com toda sua carga ideológica, mais do que em outros momentos, pregou a inquestionabilidade das verdades jurídicas: uma coisa era considerada lei e deveria ser respeitada simplesmente porque estava codificada.

No direito, muito elucidativa é a obra derridadiana chamada Força de lei: o fundamento místico da autoridade, no original: Force de loi: Le fondement mystique de l'autorité, de 1994, baseada em colóquios proferidos em universos acadêmicos. A obra é dividida em duas partes e a primeira se trata de uma exposição de Derrida na Cardozo Law School, em outubro de 1989, e se chama Do direito à justiça. Já a segunda parte, Prenome de Benjamin, foi apresentada em abril de 1990, na Universidade da Califórnia.

Nessa obra, o autor sustenta a ideia de que as leis derivam de uma espécie de fundamento místico da autoridade, e são aceitas e respeitadas em sua materialidade dentro de um discurso retórico que apenas falseia a sua própria violência.

A formatação estatal se afigura em códigos linguísticos que servem de sustento para a mudança de paradigmas, com a instauração de um novo estatuto que vai justificar a violência originária. Segundo Derrida (2010, p. 26), a desconstrutibilidade do direito se dá porque o discurso jurídico é fundado em camadas interpretativas transformáveis e seu fundamento final não é fundado, mas está construído em um alicerce místico.

O mundo é repleto de aporias, que são situações em que existe uma impossibilidade fática de se obter com concretude uma resposta para uma determinada pergunta. Trata-se de um paradoxo, um impasse, uma situação onde a dúvida impera. Para suprir tal impasse, criamse códigos linguísticos que são suplementos acobertadores, estilos de fundamentação que se destinam à dissimulação de uma inevitável aporia.

Aporia é um não-caminho, um ponto sem passagem. Para Derrida (2010, p. 27), a desconstrução do direito é a própria justiça, e é graças à indesconstrutibilidade da justiça que 
a desconstrução do direito se torna possível, pois com ela se confunde. A aporia do direito é a justiça, pois esta não pode ser experimentada, experienciada, é a experiência do impossível (DERRIDA, 2010, p. 30). A justiça é uma promessa ausente, que justamente por ser promessa, escapa da lógica binária presença/ausência, pois a promessa não é nem um presente e nem um ausente, mas algo adiado, eterno porvir. Por ser um conceito abstrato, nem jurídico e nem político, a justiça abre ao porvir a provável transformação, refundição ou refundação (DERRIDA, 2010, p. 54-55).

Justiça é singularidade, infinita, não simétrica, rebelde às regras, heterogênea, incalculável, enquanto o direito é generalidade, limitado, estatutário, estável, homogêneo, calculável. O problema é que o direito pretende ser exercido em nome de uma justiça, enquanto a justiça exige se instalar em um direito (DERRIDA, 2010, p. 42-43). A justiça é a transcendência do direito, que buscar resolver as exigências das singularidades pessoais, essas que são infinitas. É a engrenagem que move a história do direito, este que decorre do fundamento místico das leis, de uma violência originária fundante, que acabou se transformando em violência conservadora e, que, por essa razão, teme àquela primeira. $\mathrm{O}$ direito se ritualiza, passa a ser instrumento a serviço do Estado que o fundou, e esconde, através da suplementação, a violência que o instituiu. O uso brutal, ou violento do poder, acabou se transformando, por meio do processo, em um mero exercício de técnica (HESPANHA, 1992, p. 13).

Derrida trouxe a ideia de uma escritura, que é aquilo que perdeu a referência à sua origem, ou à sua arqueologia, impondo certa interdição às perguntas. $\mathrm{O}$ direito se tornou uma estrutura forte e dogmática, com fundamento místico da autoridade e, portanto, tornou-se uma escritura. Esta, para Derrida, é aquilo que deve produzir e dissimular a sua própria história. Enquanto a metáfora é algo que se reporta à origem, a escritura é justamente o oposto, onde esses traços são dissimulados (DERRIDA, 1973, p. 330). A escritura é o suplemento por excelência, pois marca o deslocamento de um significado, a fim de atingir sujeitos que estejam fora do campo de visão (DERRIDA, 1973, p. 343).

É na linguagem que Derrida vai explicitar essa problemática, onde vai surgir uma combinação dúplice entre significado e significante. A linguagem pode ser desconstruída através do traçado de um risco, com a revelação de dicotomias e a consequente marginalização de um dos termos. É a marginalização inicial a busca derridadiana, onde se investiga o significado primeiro, aquilo que é chamado de diferença (différence), que Derrida 
entende por voz, e o significante, que é a forma tomada, que vem da escrita, a que Derrida chama de diferensa ${ }^{l}$ (différance).

Ao trocar apenas uma letra, um "e" pelo "a", e sem alterar a pronúncia da palavra, traduz-se a ideia de alteridade, e dá, igualmente, o sentido de diferimento no tempo, pois a palavra francesa différer pode significar tanto diferir quanto diferenciar. Quanto ao diferimento, indica a noção de que palavras e signos não podem jamais elucidar um significado real, mas apenas significar através da busca de palavras complementares, das quais diferem, o que indica que um significado é sempre adiado, em um rastro sem fim de variados significados, gerando novos significados. Já no sentido de diferença, surge a ideia de um espaçamento, que se relaciona à simbologia de diferenciação, gerando oposições binárias e servindo de sustento hierárquico para o próprio significado.

A desconstrução, portanto, discute a presença de um significado a partir de seus marginais, em busca de um rastro que remete à falta de origem. O suplemento é uma imagem dissimuladora da presença natural do sentido à alma no logos (DERRIDA, 1973, p. 45). Em outros termos, o espelhamento da imagem à coisa, da grafia à fonia, faz a fala parecer um mero espelhamento da escrita, que acaba por tomar para si o papel de protagonista (DERRIDA, 1973, p. 44). Para Derrida (1973, p. 177), a escritura é a sombra da fala, que é a forma mais natural da expressão de um pensamento. A escrita, portanto, não é natural: nada mais é do que uma representação da presença imediata do pensamento à fala. É, assim, uma representação mediata do pensamento, pois depende da fala. Esse recurso da escritura é perigoso, pois é uma técnica adicional, ardil e artificiosa para fazer a fala presente, quando, em verdade, ela está ausente, sendo uma violência natural da língua. A escritura é a língua da morte, da finitude, pois sufoca a vida (DERRIDA, 1973, p. 20). A linguagem dessa escritura também nunca é algo fechado em si mesmo e a autoria nunca estará completa, pois toda assinatura se dá entre escritor e leitor (DERRIDA, 2002).

O próprio Estado não é uma estrutura forte. Trata-se, inclusive, de uma invenção recente na história da humanidade. O Estado Democrático de Direito é apenas uma de suas facetas, um de seus estágios, cujo inevitável fim é a ruína: valores são epocais, ficções jurídicas são facilmente substituídas. A dignidade, hoje erigida como um meta-princípio, superlativa e hipertrofiada, representa apenas uma dimensão da história do direito: a última das invenções, e, nem por isso, a melhor delas.

\footnotetext{
${ }^{1}$ Nesse artigo, optou-se pelo uso da palavra diferensa para manter o sentido da língua francesa. Na língua portuguesa, diferença e diferensa têm a mesma sonoridade, embora, na grafia, uma letra esteja trocada.
} 
O direito, como se trata de um código lingüístico, um discurso e instrumento de manutenção de poder, pauta-se no fundamento místico da autoridade. Como escritura, dissimula-se em suplementos (différance, diferensa), com o fim de mascarar sua inicial aporia. Desconstruir o direito é rasgar sua história, arrombar perspectivas ideológicas e revelar as suas aporias, que são demagogicamente ocultadas.

A grande aporia do direito, segundo Derrida (2010), é a situação paradoxal de que o direito é a universalidade que tenta lidar com singularidades, mas que, a partir do momento em que o faz, acaba aprisionando, interditando, tornando a justiça algo impossível. De outro lado, a justiça é a singularidade que pretende se instalar na generalidade, mas que, quando o faz, acaba dissipando a si mesma.

Desconstruir a dignidade humana será, portanto, decompor as ínfimas camadas de linguagem nela dissimuladas, de certos modos de condutas que estão interditos. Tal princípio, assim como todo o direito, é passível de desconstrução em fragmentos discursivos múltiplos. Enquanto suplemento jurídico do Estado Democrático de Direito, é a dignidade quem vai ocultar os velhos paradoxos, e fixar novos.

Essa suplementação para a inevitável aporia sempre tem a vocação da inquestionabilidade. A dignidade humana é para o Estado Democrático de Direito aquilo que foi a norma fundamental de Hans Kelsen no início do século XX: uma pergunta que não se pode fazer ${ }^{2}$.

Com o pós-guerra, o mundo havia conhecido os abusos cometidos pelo nazifascimo e os efeitos devastadores da bomba atômica, gerando uma enorme insegurança global. Mesmo na Alemanha, com uma cultura jurídica riquíssima, alimentada pela ética kantista e pelo formalismo da pandectística, e o próprio direito legitimado por processos constitucionais, teve o Reich de Hitler alcançado o esplendor, inclusive com o apoio da população. O novo direito alemão foi legitimado em contrassenso a todas as conquistas da cultura europeia, sob uma legitimidade positivada (HESPANHA, 1997, p. 237). Nesse contexto, estruturaram-se novos meios de opinião pública, de forma a serem questionados os métodos até então utilizados de fundação do poder, sendo o novo suplemento o poder jurígeno constituinte originário do povo, e a dignidade passou a ser a palavra da vez, inscrita no Volksgeist. É no pós-positivismo

${ }^{2}$ A norma fundamental de Hans Kelsen nada mais é do que uma construção puramente teórica. No neopositivismo, com base em especial na obra do mencionado jurista austríaco, o suplemento do direito passou a ser a norma fundamental (KELSEN, 2006). Nesse sentido, o direito estava construído em uma pirâmide normativa, e no seu topo se encontrava a Constituição. Assim, como a própria Constituição carecia de um fundamento jurídico próprio, Kelsen criou a chamada norma fundamental, ou Grundnorm, que seria autoreferencial e legítima não somente com relação às outras normas jurídicas, mas também com relação a si mesma (HESPANHA, 1997, p. 195). 
jurídico que se pensou em criar esse direito suprapositivo, que pudesse punir inclusive ações estatais cometidas sob a égide do direito vigente. Entendeu-se que, acima das leis, haveria uma legitimidade do direito corrente, retomando algumas ideias jusnaturalistas. Nessa senda, renasce a aporia da dignidade humana como um ideal supralegal indisponível mesmo pelos estados, na formatação de sua normativa. Emergiu-se não só esse metaprincípio, como também o mito fundacional da legitimação democrática, sob o pálio do Estado de Direito.

Para Derrida, a origem do direito estava na violência: direito é Gewalt, e, como tal, funda-se em estruturas de poder que apenas ocultam interesses econômicos de forças sociais dominantes (DERRIDA, 2010, p. 23). A dignidade da pessoa humana, pela luz do desconstrutivismo, pode ser desconstruída em seus ínfimos discursos, em suas verdades institucionalizadas. Assim, a dignidade humana é a maior ficção do Estado Democrático de Direito, sobre a qual é fundada a verdade de sua justiça e é mantida a correção de suas decisões, de forma altamente organizada e coordenada.

Na história do direito, a Constituição do México de 1917 usou a dignidade como valor norteador do sistema educacional do país. Posteriormente, veio a Constituição da Itália, dizendo que os indivíduos são dotados de igual dignidade social frente à lei. Por fim, a Constituição alemã, de 1949, trouxe, pela primeira vez, a dignidade da pessoa humana como um direito humano, dotado de inviolabilidade (MARTINS, 2003, p. 34). Portugal, Espanha, Bélgica, Irlanda, Venezuela, Peru, França, dentre outras tantas, trouxeram também a previsão da dignidade (MARTINS, 2003, p. 35).

Já no Brasil, a primeira Constituição a trazer a dignidade de modo expresso foi a Constituição de 1967, que, inobstante positivada, não criou empecilhos fáticos para os abusos do militarismo (MARTINS, 2003, p. 48). Contudo, trazer o conceito de dignidade humana como um fundamento do Estado Democrático de Direito, foi algo que aconteceu somente em 1988, com a Carta Constitucional Cidadã.

Assim, tem-se como fundamento da República uma nova palavra mágica, que traz uma fórmula abstrata, cujo conteúdo deve invariavelmente ser preenchido por um magistrado.

Dizer que a dignidade é da pessoa humana é no mínimo paradoxal. Encaixar uma natureza, um atributo humano, é uma ficção aristotélica de mundo.

Um paradoxo é uma contradição autofundamentável, e encaixar esta mesma dignidade de modo tão incisivo na ciência jurídica é abrir um espaço enorme, que sofre de gigantismo. Para lidar com o paradoxo de que a afirmação da dignidade é algo impossível, o 
direito cria estruturas cognitivas com o fim de solucionar o paradoxo. Essas estruturas são códigos lingüísticos que fazem a reinterpretação dos fundamentos do direito, com o rompimento do status anterior e instauração de um novo estatuto. Assim, o fundamento dignidade da pessoa humana é, em uma análise poliédrica, o estatuto do Estado Democrático de Direito.

O direito nada mais é do que um prolongamento da violência originária, que se converte em violência conservadora. Derrida (2010) distingue a violência fundadora, que é aquela que institui o direito, da violência conservadora, que é aquela que mantém o direito. A violência fundadora é a mística e a destruidora do direito é a divina. O poder, para ele, seria a mística do direito, pois existe na violência fundadora transformada em autoridade jurídica. Esse direito, que legitima o poder recém inaugurado, vai fundamentar sua existência de modo retrospectivo na mística, mascarando a violência crua. Assim, o direito não é algo que contém a violência, mas sim um prolongamento da violência originária.

No atual paradigma, o Estado Democrático de Direito omite a violência fundadora, a que a doutrina nomeia revolução, com fundamento em um poder constituinte originário do povo, igualmente um mito. Todos os discursos revolucionários justificam, obviamente, o uso da violência, de forma a materializar os novos ideais estatais. Essa força destruidora do direito nunca se dá sem violência, pois ela é justamente aquilo que suspende o direito, é a epokhé de um não-direito, pois existe na sua ausência e, de modo paradoxal, na sua presença (DERRIDA, 2010, p. 84).

Estabelecer a dignidade como uma instância jurídica é um erro: a afirmação da dignidade como um direito é um não-direito, aquele momento de suspensão da ordem vigente para instauração de uma nova. Ademais, aprisionar conceitualmente a dignidade humana é um ato de violência. Enquanto cláusula aberta que é, seu aprisionamento em uma norma fáticojurídica é a denúncia de sua própria aporia. Enquanto engrenagem, a partir do momento em que se suspende, deixa de ser dignidade.

\section{DIGNIDADE HUMANA ATRAVÉS DO ESPELHO: E o que Alice encontrou por lá.}

"'Fale inglês!' exclamou a Aguieta. 'Não sei o sentido de metade dessas palavras compridas e, o que é pior, nem acredito que você saiba!' E baixou a cabeça para dissimular um sorriso; algumas das outras aves soltaram risadinhas audíveis." (CARROLL, 2009, p. 35) 
Em um interessante momento, Conselho de uma Lagarta, Alice, no País das Maravilhas, encontra uma lagarta sonolenta fumando um narguilé.

A Lagarta pergunta para Alice: "Quem é você?", eis que Alice responde que sabia apenas quem era quando levantou pela manhã, mas que já havia passado por tantas mudanças, que não saberia mais dizer, pois receava não ser mais a mesma. Afinal, ora ela crescia de tamanho, ora diminuía: passar por tantos caminhos diferentes e mudar tantas vezes de tamanho certamente não era algo comum.

A Lagarta, insatisfeita com a resposta, continuou indagando: "Quem é você?". Cansada dos mesmos rodeios, Alice decidiu que era hora de partir, quando a Lagarta pediu que voltasse imediatamente, sob o pretexto de ter algo importante a dizer. Curiosa, Alice voltou, e a Lagarta perguntou-lhe de que tamanho ela queria ser, ensinando-lhe que deveria usar o cogumelo: um lado a faria crescer e o outro a faria diminuir.

Assim é a dignidade: talvez fosse fácil saber quem ela era pela manhã, quando fora concebida, mas já passou por tantas mudanças de tamanho e perspectivas que certamente agora é difícil dizer.

Depois desse momento, ao crescer mais alto que a copa da árvore, a menina é investigada por uma pomba, que está convencida de que Alice é uma cobra em busca de seus ovos. Ao dizer que é apenas uma menina (e refletindo sobre quantas mudanças teria passado naquele dia), a cobra não acredita, ironizando a resposta. De modo ainda mais irônico repreende: "Suponho que agora vai me dizer que nunca provou um ovo!". Então Alice responde que sim, e que meninas comem quase tantos ovos como as cobras, eis que a pomba retruca: então meninas são como uma espécie de cobra (CARROLL, 2009, p. 55-66). A dignidade, nessa perspectiva, poderia ser uma espécie de cobra, ou uma espécie de menina, a depender do ponto de vista. Não faria muita diferença no final a terminologia, já que a dignidade, como instrumento de poder estatal, poderia servir para fundamentar decisões arbitrárias. Em que pese haver a inscrição de um nome, e todo o conteúdo simbólico que este carrega, o que vai interessar ao final é em como ele é utilizado.

Em outro trecho, ao encontrar o Gato de Cheshire, Alice perguntou qual caminho deveria tomar para ir embora dali. Eis que o gato respondeu: "Depende bastante de para onde quer ir". Alice retrucou que não importava muito para onde, e o sorridente gato emendou: "Então não importa que caminho tome" (CARROLL, 2009, p. 76-77).

Adiante, Alice foi à casa da Lebre de Março, onde estava acontecendo um chá. Além do anfitrião, estavam o Chapeleiro e o Caxinguelê. Alice ficou curiosa sobre o relógio da Lebre, que marcava o dia do mês e não a hora. O Chapeleiro, sem entender, indagou por que deveria 
marcar a hora, e se por um acaso o relógio da Alice marcava o ano. Alice respondeu que obviamente não, porque o ano permanecia o mesmo por muito tempo. O Chapeleiro respondeu que era exatamente o caso de relógio dele, no que Alice ficou muito espantada, tendo dito de modo polido que não entendia bem.

Alice é desconstruída o tempo todo durante sua passagem pelo País das Maravilhas, onde as regras que imperam parecem ser muito diferentes de como ela aprendeu a enxergar as coisas. Embora estivessem falando a mesma língua, para Alice aquilo não fazia sentido (CARROLL, 2009, p. 80-82).

O que faz, nesse ponto, a obra literária, é justamente a desconstrução do pensamento lógico, da tendência de universalização. O relógio de um pode servir para determinada coisa, e do outro não. A relativização impera. Assim, a dignidade pode significar, para uns, uma determinada coisa, enquanto que para outros a dignidade é algo totalmente diferente. Quanto à passagem do Gato de Cheshire, o estilo argumentativo da dignidade pode levar para caminhos totalmente destoantes. Se não se sabe muito bem para onde ir, não importa o caminho que se tome, o que denota a insegurança da imprecisão terminológica.

Em outra aventura, Alice imagina a Casa do Espelho, um espaço encantado onde tudo é mais ou menos parecido com o mundo normal, só que ao contrário. Bom, pelo menos até onde se podia ver, já que o resto deveria ser tão diferente. Alice pensa no espelho macio, que vira uma espécie de bruma, até conseguir atravessá-lo (CARROLL, 2009, p. 164).

Nessa interessante aventura, Alice vai ao bosque onde as coisas não têm nome. Ela diz que não gostaria de perder seu nome, porque afinal teriam que lhe dar outro, o que não é certo que fosse gostar. Quando Alice entra no bosque, esquece o nome das coisas, inclusive de si mesma (CARROLL, 2009, p. 199). Derrida (1995, p. 75) defende que o nome jamais pertence a quem o recebe e também não pertence a quem o dá. $\mathrm{O}$ dom do nome dá algo que a pessoa não tem, aquilo que diz respeito à essência, algo além do ser ${ }^{3}$.

Em outra passagem, Alice viu o Rei Vermelho dormindo, e Tweedledee diz que ele estava sonhando, e que era com Alice, afinal, se ele não estivesse sonhando com ela, não estaria por lá, já que ela era somente uma espécie de sonho dele. Alice ficou inconformada com a constatação e começou a chorar. Então exclamou que, se realmente não fosse real, não conseguiria chorar. Eis que Tweedledum interrompeu-a, dizendo: "Espero que não imagine que suas lágrimas são reais!" (CARROLL, 2009, p. 213).

\footnotetext{
${ }^{3}$ A literatura apofática de Derrida (1995) é uma grande forma de recusa ao nome. Recusando a dizer o nome, surge o poder de ser. Esse modelo apofático revela um mundo despovoado de heróis e deuses, desvendando que o único conhecimento é a negação desse mesmo conhecimento. O nome de Deus é substituído por "verdadeiro", "real", "sentido", apenas outras faces de uma mesma obsessão. Essa apófase é a denúncia de que a língua é um vazio: uma declaração, uma explicação, que diz uma coisa e também o seu contrário (DERRIDA, 1995, p. 8).
} 
Através do espelho, a dignidade é somente um sonho no sonho de alguém. Passível de desconstruções, vê-se que a dignidade é um conceito polissêmico, o que certamente prejudica a sua aplicação e cria um problema de decisionismo. Acaba por se tornar um termo hipertrofiado, aberto e com forte carga ideológica, tendo em vista que sua conceituação padece de impossibilidade.

A tentativa de conceituação clássica de dignidade veio em 1785, com Immanuel Kant (2004, p. 56), na Fundamentação da Metafísica dos Costumes, quando dizia que as pessoas tinham que ser tratadas como fins em si mesmas, e não de forma objetificada, enquanto meros meios. Ele dizia que na esfera dos fins, tudo poderia ter um preço ou dignidade. Quando essa coisa tem preço, pode ser substituída por algo equivalente, já, por outro lado, se essa coisa tem dignidade, não se admite qualquer equivalência (KANT, 2004, p. 64-65).

Os constitucionalistas não se convergem quanto a uma classificação terminológica de dignidade. Ingo Sarlet (2011, p. 73) entende que a dignidade seria uma qualidade intrínseca do ser humano, que o faz merecedor de respeito e consideração. Por conta dessa qualidade, surge um complexo de direitos e deveres fundamentais, que assegurem à pessoa proteção contra qualquer ato degradante e desumano, bem como contra aquelas ações tendentes a não permitir condições mínimas para uma vida saudável. Assim, para o autor, a dignidade deve não apenas promover a dignidade em sua esfera pessoal, mas também em comunhão com a comunidade. De modo resumido, é possível inferir que o mencionado constitucionalista vê esse princípio de forma bastante apaixonada. A dignidade humana se configura mais como uma espécie de mito heróico do que uma figura real e palpável: um milagreiro emerge aos olhos do leitor, embora belamente construído. Sarlet (2011) diz, ainda, que as primeiras referências encontradas acerca da dignidade humana foram na bíblia, ao dizer que o homem foi feito à imagem e semelhança de Deus. Contudo, para ele, hoje já não há mais associação à religião, mas sim à afirmação da posição social de alguém perante a própria sociedade.

Martins (2003, p. 67) entende que a dignidade é uma cláusula aberta, que permite o surgimento de novos direitos, criando um modelo de estabilidade constitucional em que o conteúdo fundamental é constantemente adaptado, sem necessidade de reforma do texto, para amparar a evolução da sociedade.

Já Comparato (1999, p. 20), entende que a dignidade é um fim em si mesmo, e nunca um meio para se atingir determinado resultado. Tem, para ele, relação com a qualidade de vontade racional e autônoma, diferenciando o ser humano das coisas através de uma qualidade que lhe é inerente. 
Em outra linha, Barroso (2000, p. 296) define a dignidade como algo impreciso e metafísico e, em que pese a forte carga espiritual em que tal conceito se insere, não lhe resta qualquer valor jurídico.

Já Afonso da Silva (2000, p. 146) diz que a dignidade humana se encontra em um epicentro jurídico-normativo brasileiro, como fundamento para organização jurídica do Estado. Assim, o legislador optou por tratar a dignidade humana como um princípio.

Muitos outros autores se aventuraram em buscar tal definição, sem muito sucesso ou concordância. Diante dessa evidência, claro está que a dignidade é um conceito bastante vago e impreciso, e, por essa razão, oferece grande margem de liberdade judicial, gerando um problema de decisionismo.

Esse problema de idealização remonta à Grécia antiga, onde havia uma forte ideia da metafísica ${ }^{4}$. O direito, para eles, visava aproximar o ideal do real. A palavra para essa designação é phronesis, que significa prudência. Na ideologia constitucional brasileira, há forte influência da phronesis, com a retomada da lógica teoria versus prática. Aristóteles (1984) propunha, na obra Ética a Nicômaco, a articulação entre o universal e o particular, entre o mundo ideal e o mundo prático, de forma que se direcionem as ações práticas para a consecução do fim perfeito idealizado, de maneira que tudo tenha um propósito em um bem qualquer. Essa ética interpreta as ações humanas pela ótica meio e fim: a phronesis é a sabedoria prática, que se relaciona com a moralidade, cuja atividade tem relação com os humanos, enquanto seres racionais, que buscam a perfeição. Assim, a dignidade tem ínfima semelhança com essa obsessão ocidental de se buscar um requinte inexistente.

Derrida expôs em uma conferência chamada Os fins do homem, em 1968, em Nova Iorque, que a autonomia do homem é uma ilusão e que por isso era necessária uma destituição do pensamento humanista, cujas origens remontam à metafísica aristotélica ${ }^{5}$. O que Derrida pretende é algo como um abalo sísmico no radical humano, recusando o conceito de humano. Essa metafísica ressoa até os dias atuais, pois todas as designações da dignidade humana, embora haja naturais divergências, dada a sua conceituação aberta, têm em comum o fato de buscá-la como um valor inerente ao homem, ou, utilizando um termo aristotélico, da natureza

\footnotetext{
${ }^{4}$ No aristotelismo, metafísica é a investigação de realidades que ultrapassem a experiência sensível, capaz de fornecer um fundamento a todas as ciências particulares, por meio da reflexão a respeito da natureza primacial do ser: a filosofia primeira. Já no kantismo, é o estudo das formas constitutivas da razão, como fonte de princípios gerais para o conhecimento empírico. Em ambas as noções, há a ideia de um fundamento geral, algo relacionado à natureza ou à razão como elemento central autorizador.

${ }^{5}$ Importante destacar que a metafísica nunca foi um termo empregado por Aristóteles, sendo que ele usava a expressão filosofia primeira. Essa série de tratados aristotélicos, que datam do século IV a.C., foram organizados pelo filósofo Andrônico de Rodes, que deu o título à obra.
} 
do homem, da sua essência ${ }^{6}$. Para Derrida, justiça ou, em termos contemporâneos, a dignidade humana, não é direito. Justiça é aquele momento em que se fita o outro absoluto. Portanto, unificar ambas as conceituações é fazer o impossível.

Então, ao confrontar-se no espelho, a dignidade humana só pode ver aquilo a que veio: servir como suplemento autorizador do Estado Democrático, com o fim de dissimular a sua própria aporia da impossibilidade fática de ser instalada no Direito. Como fundamento da liberdade, da justiça, da paz e do desenvolvimento social, a dignidade é um mito, o maior dos mitos. Derrida (1973, p. 44) já dizia que o suplemento é como um espelho, que acaba usurpando o papel principal daquilo que representa. Ao colocar a dignidade no espelho, tudo que pode ser visto é justamente a sua aporia: a diferensa se transforma em diferença, em um efeito antimitológico da revelação da violência pura.

\section{EFEITO PÈNDULO INVERTIDO}

“'Volte para cá, querida!' Vou simplesmente olhar para cima e dizer 'Então quem sou eu? Primeiro me digam; aí, se eu gostar de ser essa pessoa, eu subo; se não, fico aqui embaixo, até ser alguma outra pessoa'... (CARROLL, 2009, p. 27)

Um fenômeno bastante comum na contemporaneidade é o panprincipiologismo (STRECK, 2010, p. 109), quando se criam novos princípios a bel prazer do intérprete. O princípio norteador de todos os demais, no Estado Democrático de Direito brasileiro, é o da dignidade humana, um conceito aberto, abstrato, que acaba favorecendo esse mercado principiológico de uma forma peculiar. A ascensão dos princípios à categoria de normas, ao lado das regras, faz emergir um aparato legal que permite uma judicialização de opções

\footnotetext{
${ }^{6}$ Em uma interessante entrevista, Derrida fala sobre o significado de homem: "Existe uma história do conceito de homem e é preciso se interrogar sobre essa história: de onde vem o conceito de homem, como o homem, ele mesmo, pensa o que é próprio do homem? Por exemplo, quando tradicionalmente se opõe o homem ao animal, se afirma que o próprio do homem é a linguagem, a cultura, a história, a sociedade, a liberdade, etc. Pode-se colocar questões sobre a validade de todas essas definições do 'próprio' e do homem e, portanto, sobre a validade do conceito de homem tal como é utilizado. Colocar questões sobre esse conceito de homem é nada ter de seguro a esse respeito. Mas isso não quer dizer ser contra o homem. Frequentemente se acusa a desconstrução de, ao colocar questões sobre a história do conceito do homem, ser inumana, desumana, contra o humanismo. Nada tenho contra o humanismo, mas me reservo o direito de interrogar quanto à história, à genealogia e à figura do homem, quanto ao conceito de próprio do homem". Entrevista à Folha de S.Paulo - Mais, em 27 de maio de 2001. Disponível em: 〈http://www1.folha.uol.com.br/fsp/mais/fs2705200111.htm >. Acesso em 21 de agosto de 2015.
} 
políticas, ideológicas e valorativas. Nessa carnavalização principiológica há, inclusive, afastamento da regra em caso de contradição, gerando um problema claro de decisionismo.

Esse discurso, puramente retórico, faz com que princípios como a dignidade sejam soluções para praticamente tudo, pois, em razão de ser um fundamento genérico, pode vir a sustentar questões que, via de regra, estariam em dimensões dissonantes. $\mathrm{O}$ uso dos princípios passou a ser indiscriminado, não havendo critérios para parar a oscilação pendular: o pivô depende de concepções particulares e a insegurança beira à obviedade.

As teorias de interpretação judiciais sempre tiveram oscilações, como um pêndulo, entre subjetividade e objetividade, algumas vezes excluindo e noutras incluindo o intérprete. A decisão acaba pendendo ora em favor da soberania e ora em favor do cidadão.

Já um pêndulo invertido é aquele em que o centro de massa se encontra acima do pivô. Um pêndulo comum tende a se estabilizar, enquanto o invertido é inerentemente instável. Deste modo, a dignidade, como um conceito aberto, acaba gerando um efeito pendular ao contrário: uma terrível insegurança para o governado.

Um interessante trecho da aventura narrada por Lewis Carroll é quando, após o encontro com a Rainha de Copas e um jogo com ela, Alice se encontra com o Grifo, que disse que era uma situação engraçada a da Rainha, já que, inobstante as constantes ameaças, esta nunca executava ninguém: era tudo fantasia dela (CARROLL, 2009, p. 109). Esse é o risco da banalização da dignidade da pessoa humana. Em que pese tal conceito não ser propriamente jurídico, o Estado Democrático de Direito dele se apropriou. Com tanto uso e tanta banalização, a palavra perde a força. Nem precisaria estar positivado para existir, mas, a partir do momento em que existe, e se usa de modo recorrente, o vocábulo perde a força, como com a Rainha de Copas que, de tanto prometer cortar as cabeças, e nunca o fazendo, virou motivo de caçoa do Grifo.

Em outro momento, no Tribunal, quando Alice vai prestar o seu depoimento sobre a execução ou não de um Valete, ela está gigante. O Rei, que estava escrevendo em seu bloco de anotações, esbravejou que a regra quarenta e dois era que todas as pessoas com mais de um quilômetro e meio de altura deveriam se retirar do Tribunal. Alice não concordou com a altura, pelo que a rainha falou que ela teria muito mais, cerca de três quilômetros. Alice diz que vai sair, mas que a regra não é válida, já que acabou de ser inventada. O Rei expõe que era a regra mais antiga do livro, enquanto Alice retrucou que então deveria ser a regra número um, e não a quarenta e dois (CARROLL, 2009, p. 140). Assim como a dignidade humana, 
novas regras são criadas a todo o momento. Nesse panprincipiologismo, o risco é imenso, já que dignidade pode fomentar decisões controversas em essência. Como o livro do rei, facilmente editável, torna mais fácil movimentar a vontade estatal. Dignidade pode dizer muito, mas quando diz muito, acaba não dizendo nada.

Durante o júri, outro interessante fato aconteceu: uma carta sem autoria, sem endereçamento, estava sendo utilizada pra incriminar o Valete, sem ao menos ser lida. Ao expor essa alegoria, Alice indaga que os versos sequer foram lidos, então não poderiam servir como instrumento probatório. Após a leitura, o Rei assegurou que havia sido o depoimento mais importante já tido no tribunal, do que Alice discordou, pois não haveria um "átomo de sentido nele". Nisso, o rei emendou: ainda melhor! Se realmente não havia sentido nele, isso os pouparia de um tanto de trabalho.

Contudo, após a insistência da menina, o rei procedeu à leitura, encaixando todos os versos na situação vivenciada no tribunal, ligando palavras esvaziadas de sentido para uma situação pseudoconcreta do júri (CARROLL, 2009, p. 142-144).

Assim é com a dignidade humana. Ao oferecer a coroa de realeza a um princípio sem especificações, com significado ausente, abre-se o espaço para significações diversas. O poema lido pelo rei, justamente por ser desprovido de sentido, tornava o trabalho do juízo ainda mais fácil. E, como vazio, é passível de encaixe em praticamente tudo. Assim como a dignidade, sofre o efeito de pêndulo invertido: quanto mais aberto um conceito é, de menos segurança dispõe o cidadão, e mais arbitrariedade incumbe ao estado-juiz.

\section{CONCLUSÃO}

Nessa análise, da justiça como motor, como rebaixar o direito para a categoria de um não-direito, em detrimento da dignidade de uma única pessoa que integre a sociedade? $\mathrm{Ou}$ então, como arrazoar o paradoxo de que uma lei com utilidade social, feita para proteger o cidadão, acaba violando-o? É possível instaurar dentro do direito esse movimento de afirmação de dignidade humana como uma negação do direito, na vertente justiça? A resposta mais acertada para essa última questão parece ser que não, já que esse momento de suspensão jurídica nada mais seria do que uma nova violência instituidora, a fomentar novos direitos: a dignidade como um instrumento previsto pelo Direito, a serviço de dizer o direito pelo nãodireito é uma aporia, uma impossibilidade objetiva, concreta. Para suprir esse paradoxo, o Estado Democrático de Direito acabou criando a figura da dignidade humana como uma espécie de totem, sem reflexos prático-jurídicos. 
A sociedade serve à lei, e não o oposto. Como disse, há tantos anos, Jean Cruet (1908, p. 332), já foi visto sociedades mudarem as leis, mas nunca foi vista uma lei mudar a sociedade. É a partir do momento em que a sociedade muda que o direito é mudado, e não o seu inverso.

A passagem mais interessante de Alice pelo mundo do Espelho é quando ela se encontra com Humpty Dumpty, e ele exclama que ganhou uma gravata nova do Rei e da Rainha Brancos, como presente de desaniversário. Alice indaga o que seria o desaniversário, e Humpty Dumpty diz que são todos os dias do ano em que não é o seu aniversário e que, por essa razão, era muito vantajoso, já que seriam trezentos e sessenta e quatro dias para o desaniversário e somente um para o aniversário. Após essa constatação numérica, Humpty Dumpty exclama: "É a glória para você!". Alice reclama que não sabe o que quer dizer "glória", ao que ele retruca com desdém: "Claro que não sabe... até que eu lhe diga. Quero dizer 'é um belo e demolidor argumento para você!'". Alice, inconformada, objeta que não era isso que glória significava, ao que Humpty Dumpty emendou que, quando utiliza uma palavra, esta significa exatamente o que ele quer que signifique: "nem mais nem menos".

Alice rebate que a questão principal é se realmente seria possível fazer com que as palavras signifiquem tantas coisas diferentes. Humpty Dumpty arrematou que, na verdade, a questão é somente uma: saber quem vai mandar (CARROLL, 2009, p. 243-245).

Ao confrontar a literatura com o direito, pode-se observar que a dignidade, enquanto termo aberto e princípio norteador do Estado Democrático, é um problema de várias facetas. Os processos sempre se formam com uma forte carga ideológica, o que causa o ocultamento da realidade social, com legitimação das condições sociais míticas, como é a justiça.

Em absoluto, o silêncio que se faz em torno do termo é proposital. Desmistificandoo, este perde a força, pois se torna epocal: apenas mais um suplemento dentre tantos outros que estiveram em tela na história do direito.

A história do Humpty Dumpty é mais atual do que deveria ser. Por trás dos paradoxos do direito, a aceitação e inquestionabilidade de um termo aberto é quase como um tesouro: um mergulho impenetrável na continuidade de verdades tão antigas quanto falsamente heróicas. Essa é a questão: dignidade pode significar exatamente o que queiram fazê-la significar, a depender de quem vai usar. O jogo de significantes e significados é infinito. Bom para o Estado e ruim para o cidadão.

\section{REFERÊNCIAS BIBLIOGRÁFICAS}

AFONSO DA SILVA, José. Poder constituinte e poder popular. São Paulo: Malheiros, 2000 . 
ARISTÓTELES. Ética a Nicômaco. Tradução de Leonel Vallandro e Gerd Bornheim da versão inglesa de W.D. Ross. São Paulo: Vitor Civita, 1984.

BARROSO, Luís Roberto. O direito constitucional e a efetividade de suas normas. Rio de Janeiro: Renovar, 2000.

CARROLL, Lewis. Aventuras de Alice no País das Maravilhas; Através do Espelho e o que Alice encontrou por lá. Tradução de Maria Luiza Xavier de Almeida Borges. Rio de Janeiro: Zahar, 2009.

COMPARATO, Fábio Konder. A afirmação histórica dos direitos humanos. São Paulo: Saraiva, 1999.

DERRIDA, Jacques. Força de lei: o fundamento místico de autoridade. 2. ed. Tradução de Leyla Perrone-Moisés. São Paulo: Martins Fontes, 2010.

Gramatologia. Tradução de Miriam Schnaiderman e Renato Janini Ribeiro. São Paulo: Perspectiva, 1973.

Salvo o nome. Tradução de Nícia Adan Bonatti. Campinas: Papirus, 1995.

A Escritura e a Diferença. Tradução de Maria Beatriz Marques Nizza da Silva. São Paulo: Perspectiva, 2002.

Os fins do homem. In Margens da filosofia. Porto: Red, s.d.

HESPANHA, Antonio Manuel. Panorama Histórico da Cultura Jurídica Europeia. Sintra: Publicações Europa-América, 1997.

O poder, o direito e a justiça numa era de perplexidades. In: Administração, Administração Pública de Macau, 15, 1992.

KANT, Immanuel. Fundamentação da Metafísica dos Costumes e Outros Escritos. Tradução de Leopoldo Holzbach. São Paulo: Martin Claret, 2004.

KELSEN, Hans. Teoria pura do direito. Tradução de João Baptista Machado. 7. ed. São Paulo: Martins Fontes, 2006.

LUHMANN, Niklas. La sociedad de la sociedad. Tradução de Javier Torres Nafarrate. Ciudad de México: Herder, Universidad Iberoamericana, Daad e Cátedra G. A. Humboldt, 2006.

MARTINS, Flademir Jerônimo Belinati. Dignidade da pessoa humana: princípio constitucional fundamental. Curitiba: Juruá, 2003.

SARLET, Ingo Wolfgang. Dignidade da pessoa humana e direitos fundamentais na Constituição Federal de 1988. 9. ed. rev. atual. Porto Alegre: Livraria do Advogado, 2011.

STRECK, Lenio. O que é isto? Decido conforme minha consciência? Porto Alegre: Livraria do Advogado, 2010. 